\title{
Prevalence of Clostridium difficile in raw beef, cow, sheep, goat, camel and buffalo meat in Iran
}

\author{
Ebrahim Rahimi ${ }^{*}$, Mohammad Jalali ${ }^{2}$ and J Scott Weese ${ }^{3}$
}

\begin{abstract}
Background: Clostridium difficile has been shown to be a nosocomial pathogen associated with diarrhoea and pseudomembranous colitis in hospitalised patients and the infection is believed to be acquired nosocomially. Recent studies have shown the occurrence of $C$. difficile in food animals which may act as a source of infection to humans. The aim of this study was to determine the occurrence of $C$. difficile in retail raw beef, cow, sheep, goat, camel and buffalo meat in Iran.

Method: From April to October 2012, a total of 660 raw meat samples from beef, cow, sheep, goat, camel and buffalo were purchased from 49 butcheries in Isfahan and Khuzestan provinces, Iran, and were evaluated for the presence of $C$. difficile using a method including selective enrichment in C. difficile broth, subsequent alcohol shock-treatment and plating onto C. difficile selective medium. C. difficile isolates were tested for the presence of toxin genes and were typed using PCR ribotyping.

Results: In this study, 13 of 660 meat samples (2\%) were contaminated with C. difficile. The highest prevalence of C. difficile was found in buffalo meat (9\%), followed by goat meat (3.3\%), beef meat (1.7\%), cow (0.94\%) and sheep meat (0.9\%). Seven of the 13C. difficile strains (53.9\%) were positive for $t c d A, t c d B$ and $c d t B$ toxin genes and were classified as ribotype 078. Four strains (30.8\%) were positive $t c d A$, and $t c d B$, and one strain (7.7\%) was possessed only $t c d B$. The remaining isolate was non-toxigenic. Susceptibilities of $13 C$. difficile isolates were determined for 11 antimicrobial drugs using the disk diffusion assay. Resistance to clindamycin, gentamycin, and nalidixic acid was the most common finding.
\end{abstract}

Conclusions: To our knowledge, the present study is the first report of the isolation of C. difficile from raw buffalo meat. This study indicates the potential importance of food, including buffalo meat, as a source of transmission of C. difficile to humans.

Keywords: Clostridium difficile, Raw meat, Camel, Buffalo, Beef, Antimicrobial resistance

\section{Background}

Clostridium difficile is a Gram-positive, anaerobic, sporeforming bacterium that has come to the forefront as an important human pathogen. It was initially dismissed as commensal in healthy infants, but was recognized as an important cause of antimicrobial-associated with diarrhoea in the 1970s. It is, now, the most commonly diagnosed cause of antimicrobial-associated and hospital-associated diarrhoea, and the cause of virtually all cases of pseudomembranous colitis [1]. C. difficile infection (CDI) more recently was described in non-hospitalized patients without

\footnotetext{
* Correspondence: ebrahimrahimi55@yahoo.com

${ }^{1}$ Department of Food Hygiene, Faculty of Veterinary Medicine, Shahrekord Branch, Islamic Azad University, P.O. Box: 166 Shahrekord, Iran

Full list of author information is available at the end of the article
}

underlying disease or a predisposing risk factor such as antimicrobial exposure, advanced age or significant comorbidities $[2,3]$.

C. difficile also appears to be an important cause of enteric disease or a commensal in a wide variety of animal species [4-6]. Food animals are an important source of enteropathogens, and $C$. difficile has been isolated from food animals such as poultry and sheep [4-7], pigs [8,9], chickens, goats and cattle [6] and calves [10]. The types of $C$. difficile found in animals and humans are often indistinguishable [10-12] raising concerns that $C$. difficile might be a zoonotic pathogen $[9,11]$. In particular, ribotype 078 is commonly found in food animals $[5,13]$ and an increasingly reported cause of community-associated CDI in humans [5,14].

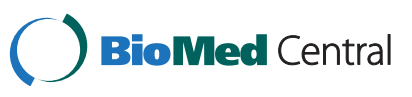


The epidemiology of CDI in Iran is poorly understood. The recent finding of ribotype 078 as the leading ribotype in a small study of CDI in humans in Iran [14] raised concern about the potential for food as a source of infection, but the prevalence of $C$. difficile in food in Iran has never been reported. The aim of this study was to determine the occurrence of $C$. difficile in retail raw beef, cow, sheep, goat, camel and buffalo meat in Iran.

\section{Methods}

\section{Sample collection}

From April to October 2012, a total of 660 raw meat samples from beef (young cattle) $(\mathrm{n}=121)$, cow (adult dairy cow) $(\mathrm{n}=106)$, sheep $(\mathrm{n}=150)$, goat $(\mathrm{n}=92)$, camel $(\mathrm{n}=124)$ and buffalo $(\mathrm{n}=67)$ were purchased unpacked from 49 butcheries in Isfahan and Khuzestan provinces, Iran. These cities are the most prominent national cultural and tourist centers located in the center and south of the country, respectively. From each city 40-55 samples (about $0.5 \mathrm{~kg} /$ sample; two sections of meat $(10 \mathrm{~cm} \times$ $10 \mathrm{~cm} \times 3 \mathrm{~cm}$ ) from neck of each carcasses were aseptically removed) were purchased monthly. All samples were placed in separate sterile plastic bags to prevent from spilling and cross contamination and were immediately transported to the laboratory in a cooler with ice packs and processed within $6 \mathrm{~h}$.

\section{Isolation and identification of $C$. difficile}

The samples were processed immediately upon arrival using aseptic techniques. The detection and isolation method used were based on the method described by Rodriguez-Palacios et al. [15] and de Boer et al. [16]. Briefly, $5 \mathrm{~g}$ of each sample was transferred to $20 \mathrm{~mL}$ of C. difficile broth (CDB; Oxoid SR0048) containing $40 \mathrm{~g} / \mathrm{l}$ proteose peptone, $5.0 \mathrm{~g} / \mathrm{l}$, disodium hydrogen phosphate, $0.1 \mathrm{~g} / \mathrm{l}$ magnesium sulphate, $2.0 \mathrm{~g} / 1$ sodium chloride, $6.0 \mathrm{~g} / \mathrm{lfructose}$ and $1.0 \mathrm{~g} / \mathrm{l}$ sodium taurocholate supplemented with $C$. difficile selective supplement (Oxoid, UK, Code: SR0173) and 5\% (v/v) defibrinated sheep blood. After incubation at $37^{\circ} \mathrm{C}$ for 10 to 15 days under anaerobic conditions $2 \mathrm{~mL}$ of the enrichment broth was added to $2 \mathrm{~mL}$ of $96 \%$ ethanol in a centrifuge tube and homogenized for $50 \mathrm{~min}$ on a shaker at room temperature. After centrifugation $(3800 \times \mathrm{g}$ for $10 \mathrm{~min})$, a loopful of the sediment was streaked onto $C$. difficile agar base (Oxoid, UK, Code: CM0601) supplemented with an antibiotic supplement for the selective isolation of C. difficile (Oxoid, UK, Code: SR0173) and 7\% (v/v) defibrinated sheep blood and the plates were incubated for $48 \mathrm{~h}$ at $37^{\circ} \mathrm{C}$, under anaerobic conditions. Three colonies per plate were subcultured onto tryptone soya agar (Oxoid, UK, Code: CM0131) and tested by standard microbiological and biochemical procedures including odour, Gram stain morphology and L-proline aminopeptidase test [4]. Crudely extracted DNA [boiling method: One colony was suspected in $500 \mu \mathrm{l}$ distilled water and after heating for $10 \mathrm{~min}$ at $95^{\circ} \mathrm{C}$, the suspension was centrifuged $(5 \mathrm{~min}, 10000 \times \mathrm{g}$ )] was used for PCR confirmation (tpi gene detection), determination of toxin gene ( $t c d A, t c d B$ and $c d t B$ ), and PCR ribotyping of isolates as performed in previous studies $[17,18]$. For assurance managed at the lab positive and negative controls were included in each batch.

The limitations of the study include the small number of C. difficile isolates which were analysed in the study and the impossibility of sampling from other areas of Iran.

\section{Antimicrobial susceptibility testing}

Antimicrobial susceptibility testing was done by the KirbyBauer disc diffusion method using Mueller-Hinton agar (HiMedia Laboratories, Mumbai, India) according to the Clinical Laboratory Standards Institute (CLSI) [19] as has been previously described [4]. The antimicrobial agents tested and their corresponding concentrations were as follows: nalidixic acid $(30 \mu \mathrm{g})$, ciprofloxacin $(5 \mu \mathrm{g})$, erythromycin $(15 \mu \mathrm{g})$, tetracycline $(30 \mu \mathrm{g})$, doxycycline $(30 \mu \mathrm{g})$, gentamicin $(10 \mu \mathrm{g})$, metronidazol $(5 \mu \mathrm{g})$, ampicillin $(10 \mu \mathrm{g})$, chloramphenicol $(30 \mu \mathrm{g})$, vancomycin $(30 \mu \mathrm{g})$, and clindamycin $(2 \mu \mathrm{g})$. After incubating the inoculated plate for $48 \mathrm{~h}$ at $37^{\circ} \mathrm{C}$, under anaerobic conditions, the susceptibility of the $C$. difficile to each antimicrobial agent was measured and the results were interpreted in accordance with interpretive criteria provided by CLSI [19].

\section{Results and discussion}

Table 1 shows the prevalence of $C$. difficile isolated from beef, cow, sheep, goat, camel and buffalo meat in two provinces, Iran. C. difficile was isolated 13/660 meat samples (Table 1). There were no significant differences $(\mathrm{P}>0.05)$ in the frequency of positive samples among the meat samples or between Isfahan $(4 / 315,1.3 \%)$ and Khuzestan (9/355, 2.3\%) ( $\mathrm{P}>0.05)$.

The highest prevalence of $C$. difficile was found in buffalo meat samples (6/67), followed by goat (3/92), beef $(2 / 121)$ and sheep (1/150) (Table 1). All the camel meat samples found to be negative. Toxigenic $C$. difficile strains ( $t c d A, t c d B$ and $c d t B$ toxin genes) were detected in $12 / 13$ of isolates. Seven of the $13 C$. difficile strains (53.9\%) were positive fortcd $A, t c d B$ and $c d t B$ toxin genes. Four strains (30.8\%) were positive $t c d A$, and $t c d B$, and one strain (7.7\%) was possessed only $t c d B$. The remaining isolate was nontoxigenic. Our finding of $C$. difficile and its toxigenic strains in meat are supported by similar reports from other counters $[9,15,16,20-23]$. The low prevalence of $C$. difficile in cow, beef, goat and sheep meat samples are comparable with those reported by others [16,20-23]. However, higher contamination rates ( $20 \%$ to $50 \%$ ) have also been reported $[9,15]$. In contrast, Von Abercron et al. [24] did not detect 
Table 1 Prevalence of Clostridium difficile detected in beef, cow, sheep, goat, camel and buffalo meat samples in Iran

\begin{tabular}{lllllll}
$\begin{array}{llllll}\text { Meat } \\
\text { sample }\end{array}$ & $\begin{array}{l}\text { No. of } \\
\text { samples }\end{array}$ & $\begin{array}{l}\text { No. of } \\
\text { C. difficile- } \\
\text { positive } \\
\text { samples }\end{array}$ & $\begin{array}{l}\text { No. of isolates } \\
\text { positive for toxins }\end{array}$ & Ribotype 078 \\
Beef & 121 & $2(1.65 \%)$ & 2 & 2 & 2 & 2 \\
Cow & 106 & $1(0.94 \%)$ & 1 & 1 & - & - \\
Sheep & 150 & $1(0.67 \%)$ & 1 & 1 & 0 & - \\
Goat & 92 & $3(3.26 \%)$ & 2 & 2 & 2 & 2 \\
Buffalo & 67 & $6(8.96 \%)$ & 5 & 6 & 3 & 3 \\
Camel & 124 & $0(0.00 \%)$ & - & - & - & - \\
Total & 660 & $13(1.97 \%)$ & 11 & 12 & 7 & 7 \\
\hline
\end{tabular}

C. difficile in meat samples other than beef. Whether this reflects a true different prevalence or is due to differences in sampling techniques employed (meat sample, carcass swab or carcass rinse fluid sample), seasonal effects [20] and/or laboratory methodologies employed in different studies is not clear.

The source of C. difficile in food products is unclear. Contamination of meat might be due to $C$. difficile residing in the gastrointestinal tract of animals, but could also originate from the hands of personnel working in the slaughterhouse, meat processing equipment or the slaughterhouse environment during the slaughtering process $[5,25,26]$. The prolonged survival of $C$. difficile spores in the environment increases the possibilities for contamination of animals and foods. Another potential source of infection that requires investigation is the presence of $C$. difficile spores in healthy muscle tissue in living animals [1].

Seven of the $13 C$. difficile strains were positive for $t c d A$, $t c d B$ and $c d t B$ toxin genes and were classified as ribotype 078. The predominance of ribotype 078 is consistent with other studies of food animals and food $[8,23,27]$. Given the presence of this strain in humans in the same region with CDI, consideration must be given as to whether food might be the source. However, further study is required to determine whether food is a reasonable source of infection.

Antimicrobial susceptibility data are presented in Table 2 . Resistance of $C$. difficile to clindomycin, gentamycin, nalidixic acid, ciprofloxacin, erythromycin, ampicillin, and tetracycline was high. These results are comparable to those reported by other investigators [6,22,28]. All the $C$. difficile isolates were susceptible to metronidazole, and vancomycin as was observed in other studies $[6,15,22]$. These two drugs are the most commonly used to treat $C$. difficile diarrhea in humans but are not used in food animals. The results of antimicrobial resistance found in this study are correlated with antibiotics usage to treat infections in food animals in Iran. In contrast,
Table 2 Antimicrobial resistance of 13 Clostridium difficile isolated from beef, cow, sheep, goat, camel and buffalo meat in, Iran

\begin{tabular}{llll}
\hline Antimicrobial agent & Sensitive & Intermediate & Resistant \\
\hline Ampicillin & $3(23.08 \%)$ & $3(23.08 \%)$ & $7(53.85 \%)$ \\
Chloramphenicol & $11(84.62 \%)$ & $2(15.38 \%)$ & $0(0.0 \%)$ \\
Ciprofloxacin & $1(7.69 \%)$ & $2(15.38 \%)$ & $10(76.92 \%)$ \\
Clindamycin & $0(0.0 \%)$ & $1(7.69 \%)$ & $12(92.31 \%)$ \\
Doxycycline & $10(76.92 \%)$ & $3(23.08 \%)$ & $0(0.0 \%)$ \\
Erythromycin & $3(23.08 \%)$ & $2(15.38 \%)$ & $8(61.54 \%)$ \\
Gentamicin & $0(0.0 \%)$ & $0(0.0 \%)$ & $13(100 \%)$ \\
Metronidazole & $13(100 \%)$ & $0(0.0 \%)$ & $0(0.0 \%)$ \\
Nalidixic acid & $0(0.0 \%)$ & $0(0.0 \%)$ & $13(100 \%)$ \\
Tetracycline & $5(38.46 \%)$ & $4(30.77 \%)$ & $4(30.77 \%)$ \\
Vancomycin & $13(100 \%)$ & $0(0.0 \%)$ & $0(0.0 \%)$ \\
\hline
\end{tabular}

many of the drugs to which the isolates were resistant (i.e. gentamicin) are commonly used in food animals.

\section{Conclusions}

This study indicates that the potential importance of food, including buffalo meat, as a source of transmission of $C$. difficile to humans. Slaughterhouses can be heavily contaminated with foodborn pathogens [29-31], the maintenance of slaughter hygiene, regular microbiological monitoring of carcasses, implementation of good manufacturing practices and a food safety system such as the HACCP system are essential to minimize the risk to the consumer. To the author's knowledge, the present study is the first report of the isolation of $C$. difficile from raw beef, cow, goat, sheepand buffalo meat in Iran. Further studies are required to determine the prevalence of $C$. difficile in meat in Iran and to explore the potential risk of human infection with $C$. difficile via consumption of meat.

\section{Abbreviations}

C. difficile: Clostridium difficile; CDI: C. difficile infection; PCR: Polymerase chain reaction; CLSI: Clinical laboratory standards institute.

\section{Competing interests}

The authors declare that they have no competing interests.

\section{Authors' contributions}

The supporting of project were performed by ER, MJ and JSW, DNA extraction, PCR techniques were performed by ER and MJ and samples collection, culture, statistical analysis and writing of manuscript were performed by ER. All authors read and approved the final manuscript.

\section{Acknowledgements}

The authors would like to thank Dr. Hassn Momtaz, Dr. Amir Shakerian, Mohammad Jahanmard and Manouchehr Momeni for the sincere help in performing technical parts of the project. We are also grateful to Pouya Parsaei, Morteza Moosavian, Iman Azadkhah, and Ali Rasooli for assistance with sampling. This work was supported by the Islamic Azad University, Shahrekord Branch-Iran grant 148. 


\section{Author details}

'Department of Food Hygiene, Faculty of Veterinary Medicine, Shahrekord Branch, Islamic Azad University, P.O. Box: 166 Shahrekord, Iran. ${ }^{2}$ Infectious Disease and Tropical Medicine Research Center and School of Food Science and Nutrition, Isfahan University of Medical Sciences, Isfahan, Iran. ${ }^{3}$ Department of Pathobiology, Ontario Veterinary College, University of Guelph, Ontario, Canada.

Received: 27 August 2013 Accepted: 8 January 2014

Published: 5 February 2014

\section{References}

1. Weese JS: Clostridium difficile in food-innocent bystander or serious threat? Clin Microbiol Infect 2010, 16:3-10.

2. Bauer MP, Veenendaal $D$, Verhoef $L$, Bloembergen $P$, van Dissel JT, Kuijper EJ: Clinical and microbiological characteristics of community-onset Clostridium difficile infection in The Netherlands. Clin Microbiol Infect 2009, 15:1087-1092

3. Wilcox MH, Mooney L, Bendall R, Settle CD, Fawley WN: A case-control study of community-associated Clostridium difficile infection. J Antimicrob Chemother 2008, 62:388-396.

4. Harvey RB, Norman KN, Andrews K, Hume ME, Scanlan CM, Callaway TR, Anderson RC, Nisbet DJ: Clostridium difficile in poultry and poultry meat. Foodborne Pathog Dis 2011, 8:1321-1323.

5. Keessen EC, Gaastra W, Lipman LJA: Clostridium difficile infection in humans and animals, differences and similarities. Vet Microbiol 2011 153:205-217.

6. Simango C, Mwakurudza S: Clostridium difficile in broiler chickens sold at market places in Zimbabwe and their antimicrobial susceptibility. Int J Food Microbiol 2008, 124:268-270.

7. Al Saif N, Brazier JS: The distribution of Clostridium difficile in the environment of South Wales. J Med Microbiol 1996, 45:133-137.

8. Songer JG, Trinh HT, Killgore GE, Thompson AD, McDonald LC, Limbago BM: Clostridium difficile in retail meat products, USA 2007. Emerg Infect Dis 2009, 15:819-821.

9. Songer JG: Clostridia as agents of zoonotic disease. Vet Microbiol 2010, 140:399-404.

10. Rodriguez-Palacios A, Stämpfli HR, Duffield T, Peregrine AS, Trotz-Williams LA, Arroyo LG, Brazier JS, Weese JS: Clostridium difficile PCR ribotypes in calves, Canada. Emerg Infect Dis 2006, 12:1730-1736.

11. Goorhuis A, Debast SB, Van Leengoed LA, Harmanus C, Notermans DW, Bergwerff AA, Kuijper EJ: Clostridium difficile PCR ribotype 078: an emerging strain in humans and in pigs? J ClinMicrobio/ 2008, 46:1157-1158

12. Rupnik $M$, Wilcox $M H$, Gerding DN: Clostridium difficile infection: new developments in epidemiology and pathogenesis. Natur Rev Microbiol 2009, 7:526-536.

13. Pirs T, Ocepek M, Rupnik M: Isolation of Clostridium difficile from food animals in Slovenia. J Med Microbiol 2008, 57:790-792.

14. Jalali M, Khorvash F, Warriner K, Weese JS: Clostridium difficile infection in an Iranian hospital. BMC Res Notes 2012, 5:159. 10.1186/1756-0500-5-159.

15. Rodriguez-Palacios A, Staempfli HR, Duffield T, Weese JS: Clostridium difficile in retail ground meat Canada. Emerg Infect Dis 2007, 13:485-487.

16. de Boer E, Zwartkruis-Nahuis A, Heuvelink AE, Harmanus C, Kuijper EJ: Prevalence of Clostridium difficile in retailed meat in The Netherlands. Int J Food Microbiol 2011, 144:561-564.

17. Bidet P, Barbut F, Lalande V, Burghoffer B, Petit J: Development of a new PCR-ribotyping method for Clostridium difficile based on ribosomal RNA gene sequencing. FEMS Microbiol Lett 1999, 175:261-266.

18. Lemee L, Dhalluin A, Testelin S, Mattrat M, Maillard K, Lemeland J, Pons JL: Multiplex PCR targeting tpi (triose phosphate isomerase), tcdA (Toxin A), and $t c d B$ (Toxin $B$ ) genes for toxigenic culture of Clostridium difficile. J Clin Microbiol 2004, 42:5710-5714.

19. Clinical and Laboratory Standards Institute (CLSI): Performance Standards for Antimicrobial Susceptibility Testing; 7th ed, CLSI document M11-A7. Wayne, PA: Clinical and Laboratory Standards Institute; 2007.

20. Rodriguez-Palacios A, Reid-Smith RJ, Staempfli HR, Daignault D, Janecko N, Avery BP, Martin H, Thompson AD, McDonald LC, Limbago B, Weese JS: Possibility of seasonality of Clostridium difficile in retail meat, Canada. Emerg Infect Dis 2009, 15:802-805.

21. Bouttier S, Barc MC, Felix B, Lambert S, Collignon A, Barbut F: Clostridium difficile in ground meat, France. Emerg Infect Dis 2010, 16:733-735.
22. Jöbstl M, Heuberger S, Indra A, Nepf R, Köfer J, Wagner M: Clostridium difficile in raw products of animal origin. Int J Food Microbiol 2010, 138:172-175.

23. Curry SR, Marsh JW, Schlackman JL, Harrison LH: Prevalence of Clostridium difficilein uncooked ground meat products from Pittsburgh, Pennsylvania. Appl Environ Microbiol 2012, 78:4183-4186

24. Von Abercron SMM, Karlsson F, Wigh GT, Wierup M, Krovacek K: Low occurrence of Clostridium difficile in retail ground meat in Sweden. J Food Prot 2009, 72:1732-1734.

25. Baker AA, Davis E, Rehberger T, Rosener D: Prevalence and diversity of toxigenic Clostridium perfringens and Clostridium difficile among swine herds in the midwest. App/ Environ Microbiol 2010, 76:2961-2967.

26. Thitaram SN, Frank JF, Lyon SA, Siragusa GR, Bailey JS, Lombard JE, Haley CA, Wagner BA, Dargatz DA, Fedorka-Cray PJ: Clostridium difficile from healthy food animals: optimized isolation and prevalence. J Food Prot 2011, 74:130-133.

27. Avbersek J, Janezic S, Pate M, Rupnik M, Zidaric V, Logar K, Vengust M, Zemljic M, Pirs T, Ocepek M: Diversity of Clostridium difficile in pigs and other animals in Slovenia. Anaerobe 2009, 15:252-255.

28. Indra A, Schmid D, Huhulescu S, Hell M, Gattringer R, Hasenberger P, Fiedler A, Wewalka G, Allerberger F: Characterization of clinical Clostridium difficile isolates by PCR ribotyping and detection of toxin genes in Austria, 2006-2007. J Med Microbiol 2008, 57:702-708.

29. Rahimi E, Momtaz H, Bonyadian M: PCR detection of Campylobacter sp. from turkey carcasses during processing plant in Iran. Food Control 2010 21:692-694.

30. Rahimi E, Momtaz H, Ameri M, Ghasemian Safai H, Ali Kazemi M: Prevalence and antimicrobial resistance of Campylobacter species isolated from chicken carcasses during processing in Iran. Poult Sci 2010, 89:1015-1020.

31. Rahimi E, Momtaz H, Nozarpour N: Prevalence of Listeria spp., Campylobacter spp., and Escherichia coli 0157:H7 isolated from camel during processing. BJVM 2010, 13:179-185.

doi:10.1186/1471-2458-14-119

Cite this article as: Rahimi et al:: Prevalence of Clostridium difficile in raw beef, cow, sheep, goat, camel and buffalo meat in Iran. BMC Public Health 2014 14:119.

\section{Submit your next manuscript to BioMed Central and take full advantage of:}

- Convenient online submission

- Thorough peer review

- No space constraints or color figure charges

- Immediate publication on acceptance

- Inclusion in PubMed, CAS, Scopus and Google Scholar

- Research which is freely available for redistribution 